ISSN (print) : 2722-7316

e-ISSN : :2723-1275

https://ejournal.uhn.ac.id/index.php/humaniora/

\title{
TRANSAKSI JUAL BELI SAMPAH DALAM PERSPEKTIF HUKUM PERLINDUNGAN KDNSUMEN (Studi pada Koperasi Bank Sampah Sunggal Mandiri, Paya Bakung Kabupaten Deli Serdang)
}

\author{
Debora', Divo Anantama² \\ Fakultas Hukum Universitas HKBP Nommensen, Medan \\ debora回uhn.ac.id'divaanantama回uhn.ac.id ${ }^{2}$
}

\author{
Info Artikel \\ Diterima : 12 April 2021 \\ Revisi : 20 Mei 2021 \\ Terbit : : 28 ل Јuni 2021

\section{Key wards:} \\ Words Waste Bank, Consumen, \\ Agreement
}

\section{Kata Kunci:}

Bank Sampah, Konsumen, Perjanjian

\section{Corresponding Author :}

Debora', Divo Anantama²

Email: debora国uhn.ac.id'

divoanantama回uhn.ac.id ${ }^{2}$

\section{Abstract}

Waste management efforts in North Sumatra aге сагried out in various ways, including through the Waste Bank program. Saving waste in the waste bank is carried out by buying and selling waste. The type of research used is empirical legal research. The practice of buying and selling waste at the Sunggal Mandiri Garbage Bank with residents, namely in the collection, management, and utilization of waste, where the community directly contributes to the collection and sorting of waste, while the Garbage Bank is tasked with managing waste sa that waste can be disposed of. In article 4 paragraph I of the Consumer Protection Act №. 8 of 1999 , consumers or property buyers have rights including comfort, security and safety in consuming products and services and choosing them according to the exchange rate and conditions according to the agreement.

\section{Abstrak}

Upaya penanggulangan sampah di Sumatera Ltara dilakukan dengan berbagai сага antara lain melalui program Bank Sampah. Menabung sampah di dalam Bank sampah dilakukan dengan ransaksi jual beli sampah. Jenis penelitian yang digunakan adalah penelitian hukum empiris Praktek jual beli sampah di Bank Sampah Sunggal Mandiri dengan warga yaitu dalam pengumpulan, pengelolaan, dan pemanfaatan sampah, dimana masyarakat yang langsung memberikan kontribusinya dalam pengumpulan dan pemilahan sampah, sedangkan Bank Sampah bertugas untuk mengelola sampah agar sampah yang telah disetorkan dapat memberikan nilai ekonomis lebih Pada pasal 4 ayat I Undang-Undang Perlindungan Konsumen No.8 tahun 1999, konsumen atau pembeli properti memiliki hak antara lain kenyamanan, keamanan, dan keselamatan dalam mengkonsumsi produk maupun jasa serta memilihnya sesuai dengan nilai tukar dan kandisi sesuai perjanjian 


\section{PENDAHULLUAN}

Sampah memiliki berbagai macam jenis yaitu sampah padat, sampah cair, dan sampah dalam bentuk gas. Berdasarkan zat kimia yang dikandungnya, sampah dikelompokan menjadi sampah anorganik dan sampah organik. Sampah anorganik adalah sampah yang umumnya tidak dapat membusuk, misalnya logam atau besi, pecahan gelas, dan plastik. Sampah organik adalah jenis sampah yang dapat membusuk, misalnya sisa-sisa makanan, daun-daun, dan buah-buahan.'

Sampah selama ini dipandang sebagai barang yang tidak berguna sehingga harus "dibuang" di tempat sampah. Dampak negatif sampah seperti pencemaran lingkungan sekitar, lingkungan menjadi kotor, timbulnya berbagai macam penyakit dan rusaknya ekosistem. Dari segi keseimbangan lingkungan, kesehatan, keamanan, pencemaran udara, pencemaran air dan pencemaran tanah menyebabkan manusia memandang negatif sampah. Pandangan tersebut mengakibatkan membentuk sebuah paradigma bahwa sampah adalah barang kotor, berbau, menijijkan, tidak berguna, dan harus dibuang. ${ }^{2}$

Pertumbuhan ekanami yang tinggi di Kata berjalan seiring dengan pertumbuhan penduduk. Hal ini membuat masalah-masalah baru seperti urbanisasi, kepadatan penduduk dan juga volume sampah yang terus meningkat. Sampah merupakan masalah yang dialami oleh hampir seluruh kota di Indanesia sehingga tak heran bahwa sampah merupakan masalah nasional. Produksi sampah perkataan Indonesia sebesar 38,5 juta ton/tahun atau rata-rata sebesar 200.000 ton/hari. Produksi sampah Khususnya Kota Medan misalnya saja pada Tahun 2013 volume sampah yang dihasilkan masyarakat Kota Medan setiap hari berkisar 1700 ton, sedangkan Tahun 2015 mencapai 1900 ton perhari, dan pada Tahun 2019 meningkat menjadi 2000 ton perhari. Jika dihitung dalam setahun maka volume sampah Tahun 2019 mencapai 73000 ton. Data pada UPT Pengelolaan Sampah Dinas Lingkungan Hidup Pravinsi Sumatera Utara 13\% dari jumlah tersebut (9490 ton) berupa sampah plastik.

Sampah selalu menjadi permasalahan masyarakat yang selalu menimbulkan konflik struktural antara pemerintah dan rakyat yang disebabkan kurangnya pemahaman masyarakat terhadap sampah. Masyarakat yang masih memandang sampah dari sisi negatif padahal sampah masih bisa dirubah atau didaur ulang. Dengan diberlakukannya perubahan pola pengelolaan sampah yang bertumpu pada pengurangan pemerintah berupaya mengurangi permasalahan sampah.

'Eni Setyawati. 2014. Sampah Aktualisasi Nilai-Nilai Islam, Ekanami Sasia/ dan Budaya. Yogyakarta : IAIN Tulungagung Press. Hal: 36 ${ }^{2}$ /bid. Hal: 38

Transaksi dual Beli Sampah Dalam Perspektif Hukum Perlindungan Kansumen (Studi pada Kaperasi Bank Sampah Sunggal Mandiri, Paya Bakung Kabupaten Deli Serdang) 
Upaya penanggulangan sampah di Sumatera Utara khususnya di kata Medan dilakukan dengan berbagai hal antara lain program Bank Sampah. Bank Sampah merupakan kegiatan bersifat sasial yang mengajarkan masyarakat untuk memilah sampah serta menumbuhkan kesadaran masyarakat dalam pengelalaan sampah secara bijak pada gilirannya akan mengurangi sampah yang diangkut ke TPA. Bank Sampah adalah sebagai suatu program pengelalaan lingkungan yang dirancang oleh Pemerintah Sumatera Utara. Bank sampah adalah suatu sistem pengelolaan sampah kering secara kolektif yang mendarong masyarakat untuk berperan serta aktif di dalamnya. Sistem ini akan menampung, memilah, dan menyalurkan sampah bernilai ekonami pada pasar sehingga masyarakat mendapat keuntungan dari menabung sampah. ${ }^{3}$

Menabung yang dimaksudkan oleh Bank sampah Sunggal Mandiri tidak seperti menabung pada Bank umumnya. Dalam Bank umumnya istilah menabung atau tabungan adalah simpanan yang berasal dari pendapatan yang tidak dibelanjakan dan bisa dilakukan oleh perarangan maupun instansi tertentu. Tabungan tersebut bisa diambil kapan saja tanpa terikat oleh waktu. Bahkan bisa ditarik tunai secara mandiri melalui fasilitas ATM yang diberikan oleh bank.

Transaksi menabung yang dipraktekan yaitu warga mengumpulkan sampah-sampah rumah tangga, sampah rumah tangga termasuk dalam sampah jenis anorganik yaitu sampah yang tidak dapat membusuk, seperti logam, besi, pecahan gelas, plastik, kertas dan sisa-sisa bahan-bahan padat lain hasil kegiatan rumah tangga. Sampah dikumpulkan setiap hari oleh pemilik sampah yang diletakan dalam tong sampah atau plastik khusus sampah kering, kemudian selama I bulan sekali atau sebelum sebulan sampah sudah banyak, operatar mengambilnya dengan cara warga menghubunginya lewat telefon untuk mengambil sampah. Namun ada juga operator yang bertugas rutin mengambil sampah setiap I minggu 2 x dari pukul 07.00 sampai pukul 12.00 WIB. Setelah operatar mengambil sampah warga, sampah tersebut dipilah berdasarkan jenis dan ditimbang. Seperti itulah yang dilakukan oleh operatar dan nasabah sampai 6 bulan baru warga memperoleh uang dari bank sampah atas hasil sampah yang mereka tabung setiap bulannya atau minimal pemberian uang kepada nasabah setelah 2 minggu sampah terkumpul atau ditabungkan.

Menabung sampah yang terjadi di dalam Bank sampah Sunggal Manidiri faktanya terjadi transaksi jual beli sampah. Di mana si penjual yang disebut sebagai nasabah menjual sampahnya kepada Bank sampah Sunggal Mandiri sebagai pembeli dengan sistem menabung.

${ }^{3}$ Eka Utami. 2013. Buku Panduan Sistem Bank Sampah dan ID Kisah Sukses. Jakarta: Yayasan Unilever Indanesia. Hal: 57 
Bank Sampah Sunggal Mandiri dikerjakan oleh beberapa warga di lingkungan sekitar Kaperasi yang telah mengumpulkan sampah kering untuk dijual, sehingga sampah tersebut menjadi sesuatu yang bernilai ekonamis. Dengan adanya bank sampah tersebut masyarakat dapat terbantu untuk menambah penghasilan sehari-hari, khususnya masyarakat di Jalan Paya Bakung, Dusun VII Simpang Diski, Kabupaten Deliserdang, Sumatera Utara. Terbukti dari menabung di bank sampah tersebut bisa membantu memenuhi kebutuhan rumah tangga seperti membeli beras, garam, minyak dan kebutuhan pokok lainnya. Sehingga dari usaha pengumpulan sampah tersebut telah membantu masyarakat sekitar Jalan Paya Bakung, Dusun VII Simpang Diski, Kabupaten Deliserdang, Sumatera Utara untuk menambah pendapatan, sekaligus menggurangi pengangguran.

Proses jual beli dalam Bank Sampah Sunggal Mandiri tersebut yaitu bagi penambung individu (penjual) mengumpulkan sampahnya di tong sampah yang telah disediakan oleh Bank Sampah Sunggal Mandiri, sedangkan yang menabung (penjual) secara kelampak, mereka mengumpulkan sampahnya ke gudang sampah yang mereka miliki. Kemudian selama I bulan sekali sampah tersebut diambil oleh operatar, namun jika sebelum I bulan sampah tersebut sudah banyak, operator dapat mengambilnya dengan cara dihubungi lewat telfon oleh penabung (penjual).

Qperator tersebut hanya melakukan pengambilan sampah saja, tidak melakukan pencatatan maupun penimbangan di tempat saat mengambil sampah di rumah penabung (penjual). Proses penimbangan dan pencatatan dilakukan oleh operator pada saat di gudang bank sampah, sehingga nasabah tidak mengetahui dan melihat secara jelas proses penimbangan dan pencatatan sampah tersebut. Jumlah sampah yang disetorkan oleh penabung (penjual) ke bank sampah tidak pasti, tergantung jenis sampah yang mereka jual atau tabung pada saat operatar mengambilnya. Penabung (penjual) menerima uang dari bank sampah atas hasil sampah yang mereka tabung tidak pasti waktunya, menunggu bank sampah menelefon penabung atau penjual. Jadi penjual menyerahkan sepenuhnya transaksi penjualan sampah tersebut kepada operator dan menerima uang secara bersih tanpa mengetahui prosesnya. Namun operator tersebut bekerja bukan karena atas penyerahan kewajiban penjualan yang diserahkan oleh penjual akan tetapi, operatar bekerja atas dasar tanggung jawab yang diberikan oleh pembeli (Bank sampah) tersebut.

Jadi dalam transaksi tersebut terdapat beberapa permasalahan, barang yang diperjual belikan apakah termasuk barang yang bermanfaat, karena pemahaman masyarakat terkait sampah adalah barang yang sudah tidak berguna lagi, sehingga apakah barang yang sudah tidak berguna atau dibuang dapat diperjual belikan, selain itu dalam proses transaksi atau penimbangan sampah setelah dilakukan pemilahan oleh operator, nasabah (penjual) tidak melihat secara langsung proses penimbangan, tidak diperbolehkan menjual barang yang 
tidak diketahui ukurannya, karena tidak ada kejelasan dengan takarannya bisa terjadi sampah yang diberikan oleh penjual tidak semuanya ikut tertimbang. Selain itu penjual dapat menerima uang dengan waktu yang tidak pasti, menunggu kabar atau menunggu dihubungi oleh bank sampah.

Berdasarkan uraian diatas, maka yang menjadi pokok permasalahan adalah bagaimana praktik perjanjian jual beli sampah dan bagaimana perlindungan konsumen terhadap produk daur ulang (Studi Kaperasi Bank Sampah Sunggal Mandiri, Paya Bakung, Dusun VII, Kabupaten Deli Serdang)".

\section{METODE PENELITIAN}

Jenis penelitian dalam tulisan ini adalah jenis penelitian hukum empiris, yaitu penelitian hukum yang objek kajiannya meliputi ketentuan dan mengenai pemberlakuan atau implementasi ketentuan hukum normatif (kndifikasi, Undang-Undang atau kantrak) secara in action/in abstracto pada setiap peristiwa hukum yang terjadi dalam masyarakat (in concreta). Data yang diperlukan adalah data primer sebagai sumber data utama di samping data sekunder sebagai sumber data pendukung. Teknik pengumpulan data penelitian ini adalah teknik wawancara dan studi kepustakaan (library research), berdasarkan teknik ini, informasi yang diperoleh dari berbagai sumber, waktu diperolehnya dan tempat akan di catat secara cermat.

\section{HASIL DAN PEMBAHASAN}

\section{Praktik Jual Beli Sampah di Bank Sampah Sunggal Mandiri}

Bank sampah bukanlah bank konvensional atau lembaga keuangan bank dan nan bank. Tapi bank sampah mempunyai kegiatan dalam lingkup layanan di bidang persampahan. Sampah yang umumnya dibuang tapi dianggap bernilai ekonamis dan bermanfaat. Para nasabahnya bisa menabung sampah dan mendapatkan uang di kemudian hari. Dalam aktifitasnya seperti bank secara umum, memiliki buku tabungan, slip setaran, serta catatan buku induk setoran. Termasuk catatan yang berguna untuk mengecek harga sampah yang dijual ke pengepul atau industri daur ulang.

Hadirnya Bank Sampah merupakan salah satu bukti akan kepedulian masyarakat akan lingkungannya. Bank sampah adalah tempat menabung sampah. Bank Sampah bekerja sama dengan masyarakat dalam mengumpulkan sampah. Masyarakat sebagai produsen sampah, sudah terlebih dahulu menyortir atau memilah sampah di rumahnya masing-masing. Setelah sampah dipilah oleh masyarakat, barulah sampah pilihan tersebut disetarkan ke bank sampah. Dalam proses pengumpulan ini, sampah ditimbang dihadapan nasabah, kemudian petugas menuliskan sejumlah nilai rupiah sampah menurut klasifikasinya di buku tabungan nasabah. Sampah yang sudah terkumpul di Bank Sampah, kemudian diolah menjadi beberapa kerajinan tangan atau pun pupuk 
kumpas. Dan sampah-sampah yang tidak bisa dijadikan kerajinan tangan akan dijual ke pengepul dan ke pihak yang sudah menjadi mitra Bank Sampah.Sistem penyetoran dan penjualan di Bank Sampah Sunggal Mandiri dapat dilihat pada bagan alir berikut:

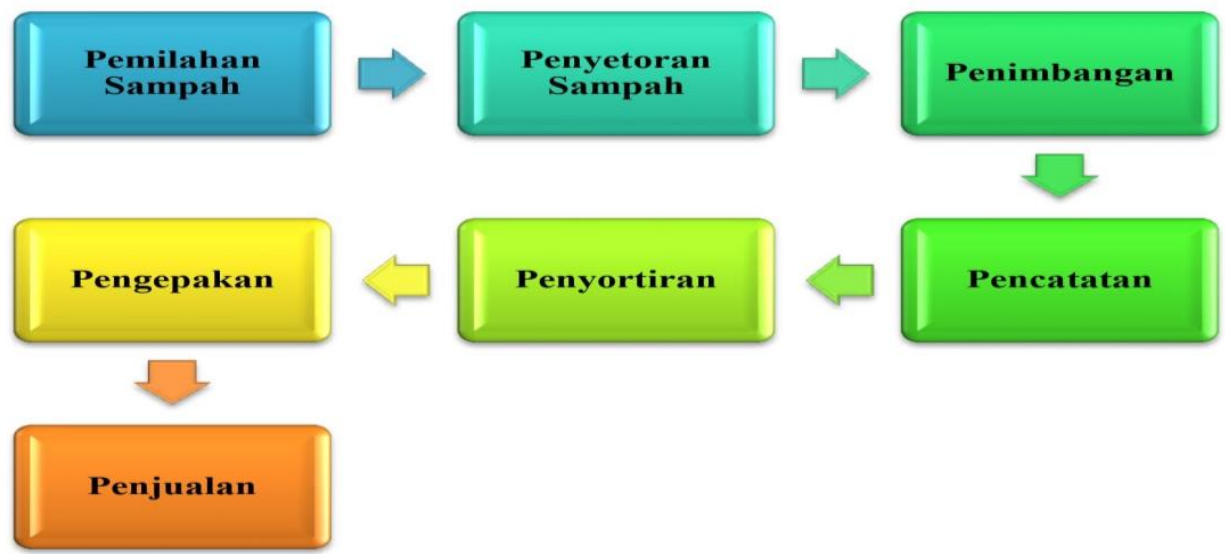

\section{Gambar 4.1 \\ Proses Pelaksanaan Jual Beli Sampah di Bank Sampah Sunggal Mandiri}

I. Pemilahan Sampah

Nasabah harus memilah terlebih dahulu sampah di rumah masing-masing sebelum di bawa ke Bank Sampah Sunggal Mandiri

2. Penyetaran Sampah

Nasabah menyetor sampah sesuai dengan jadwal buka Bank Sampah Sunggal Mandiri, yaitu pada hari Senin-Jum'at pukul 09:00-16.00 WIB. Bagi nasabah yang memiliki kendala waktu untuk melakukan penyetaran langsung, pada waktu-waktu tertentu, pada pukul 10:00-12:00 beberapa karyawan dari Bank Sampah Sunggal Mandiri akan datang kerumah nasabah guna melakukan penyetoran dengan sistem jemput bola.

3. Penimbangan

Proses penimbangan dilakukan oleh pihak Bank Sampah Sunggal Mandiri. Sampah yang dicampur harganya lebih murah daripada sampah yang sudah dipisah.

4. Pencatatan

Setelah sampah ditimbang selanjutnya dikanversikan ke dalam bentuk rupiah dan ditulis di buku tabungan nasabah.

5. Penyortiran

Transaksi dual Beli Sampah Dalam Perspektif Hukum Perlindungan Kansumen (Studi pada Kaperasi Bank Sampah Sunggal Mandiri, Paya Bakung Kabupaten Deli Serdang) 
Sampah yang sudah terkumpul, dipisah sesuai jenisnya oleh pihak Bank Sampah Sunggal Mandiri, biasanya terdiri dari dus, batol, plastik, besi dan sebagainya.

6. Pengepakan

Setelah disartir, selanjutnya sampah disusun dengan rapih dan di kemas untuk di angkut ke pengepul atau ke pihak yang sudah menjadi mitra Bank Sampah Sunggal Mandiri.

7. Penjualan

Sampah yang sudah di kemas, selanjutnya akan di jual ke pengepul atau ke pihak yang sudah menjadi mitra Bank Sampah Sunggal Mandiri untuk mendapat keuntungan maksimal.

Bila kita melihat transaksi yang dilakukan oleh bank sampah dan nasabah selintas saja, maka kita akan menilai bahwa transaksi yang dilakukan seperti transaksi biasa. Dalam jual beli, jika si penjual telah mendapatkan hak atas kepindahan kepemilikan barang dan si pembeli telah mendapatkan barang yang diinginkan maka hubungan antara penjual dan pembeli telah terputus. Ini semua tidak sama dengan hal kerjasama. Di dalam kerjasama, hubungan ini bersifat terus menerus selama bisnis yang dilakukan tetap ada dan salah satu pihak tidak memutuskan hubungannya atas lainnya.

Dari kegiatan di atas, kita bisa melihat bahwa kedua belah pihak memberikan kantribusinya dalam mengelola sampah yang tidak bernilai apa-apa berubah menjadi barang yang mempunyai nilai ekonomis. Nasabah/masyarakat memilah sampah rumah tangga yang ada di rumah mereka masing-masing sebelum disetarkan ke bank sampah. Sedangkan Bank Sampah mengelola sampah yang telah disetarkan tadi untuk dijadikan kerajinan tangan dan kompos. Sisa dari sampah yang dikumpulkan akan dijual ke pengepul.

Pelaksanaan program bank sampah di Kota Medan masih mempunyai beberapa kendala antara lain. ${ }^{4}$

a) Kurangnya kesadaran masyarakat

Kesadaran dan kemauan masyarakat masih rendah meski sudah mengetahui program bank sampah yang disampaikan saat sasialisasi. Masih ada warga yang cenderung tak mau tahu dan kurang peduli dengan kegiatan lingkungan. Kesadaran masyarakat terhadap lingkungan juga sangat berpengaruh pada kepatuhan hukum baik langsung maupun tidak langsung. Dalam masyarakat maju, faktor kesadaran hukum berpengaruh langsung pada kepatuhan hukum masyarakat. Orang patuh pada hukum karena mereka memang jiwanya sadar bahwa mereka membutuhkan hukum dan hukum itu bertujuan baik dan telah mengatur masyarakat secara baik, benar dan adil. Pada masyarakat yang masih

\footnotetext{
${ }^{4}$ Wawancara dengan Nofizar selaku Ketua Koperasi Bank Sampah Sunggal Mandiri pada hari Kamis, 27 Mei 2021 pukul l3.15 WIB. 
tradisional, kesadaran hukum masyarakat berpengaruh secara tidak langsung pada kepatuhan hukumnya. Mereka patuh pada hukum bukan karena keyakinannya secara langsung bahwa hukum itu baik atau karena mereka membutuhkan hukum, melainkan mereka patuh pada hukum lebih karena diminta, bahkan dipaksanakan oleh para pemimpinnya (formal atau informal) atau karena perintah agama atau kepercayaannya. Jadi dalam hal pengaruh tidak langsung ini, kesadaran dari masyarakat lebih untuk patuh kepada pemimpin, agama, kepercayaannya, dan sebagainya.

b) Partisipasi masyarakat masih kurang

Partisipasi masyarakat masih kurang terutama para nasabahnya untuk memilah dan memilih sampah rumah tangganya serta menyetorkannya ke bank sampah.

c) Jarak Bank Sampah dengan rumah Nasabah

Banyak warga yang mengeluhkan jarak bank sampah dengan rumah mereka cukup jauh dan pihak bank sampah belum membentuk pos-pos di masing- masing dusun terutama yang jauh dari bank sampah, di mana pos-pos ini jadi pusat pengumpulan sampah dari masyarakat yang rumahnya jauh dari bank sampah

d) Harga Bersaing

Bank sampah mempunyai kendala dengan harga satuan kilo sampah, bank sampah harus bersaing dengan para tukang loak barang bekas keliling. Karena tukang loak ini berani membayar lebih tinggi dari harga yang ditentukan bank sampah, misalkan untuk Koran tukang loak memberi harga Rp I.000 sedangkan di bank sampah dihargai Rp 700 .

e) Transportasi

Bank sampah mengalami kendala dalam transportasi, bank sampah harus menyewa dump truck untuk mengangkut sampah perusahaan yang volume sampahnya tidak sedikit.

\section{Perlindungan Konsumen terhadap produk daur ulang di Bank Sampah Sunggal Mandiri}

Perlindungan terhadap knnsumen dipandang secara material maupun formal makin terasa sangat penting, mengingat makin maju ilmu pengetahuan dan tekhnolagi yang merupakan penggerak bagi produktivitas dan efesiensi produser atas barang atau jasa yang dihasilkan dalam rangka mencapai sasaran usaha. Dalam rangka mengejar dan mencapai kedua hal tersebut. Akhirnya, baik langsung apa tidak langsung, konsumenlah yang umumnya akan merasakan dampaknya. Dengan demikian, upaya-upaya memberikan perlindungan yang 
memadai terhadap kepentingan knnsumen merupakan suatu hal yang penting dan mendesak untuk segera mendapatkan solusi terutama di Indonesia. ${ }^{5}$

Dilihat dari sejarahnya, gerakan perlindungan konsumen di Indanesia baru dipopulerkan sekitar tahun 20 tahun yang lalu, yakni dengan berdirinya suatu lembaga swadaya masyarakat (Nongovernmental organization) yang bernama Yayasan Lembaga Kansumen Indonesia (YLKI). Setelah YLKI, kemudian muncul beberapa arganisasi serupa, antara lain Lembaga Pembinaan dan Perlindungan Konsumen (LP2K) di Semarang yang berdiri sejak Februari 1988. Kemudian bergabung sebagai anggata Consumers International (CI) pada tahun 1990. Di luar itu, saat ini cukup banyak lembaga swadaya masyarakat serupa berorientasi pada kepentingan pelayanan konsumen, seperti Yayasan Lembaga Bina Kansumen Indonesia (YLBKI) di Bandung dan perwakilan YLKI di berbagai provinsi di Tanah Air. Gerakan konsumen di Indonesia, termasuk yang diprakasai YLKI mencatat prestasi besar setelah naskah akademik UUPK berhasil dibawa ke DPR. Selanjutnya rancangannya disahkan menjadi undang-undang. ${ }^{6}$

Sesungguhnya peran hukum dalam konteks ekonomi adalah menciptakan ekonomi dan pasar yang kompetitif. Perlindungan konsumen harus mendapat perhatian yang lebih, karena investasi asing telah menjadi bagian pembangunan ekonami Indonesia, dimana ekonami Indanesia juga berkaitan dengan ekonomi dunia. Persaingan internasional dapat membawa implikasi negative bagi konsumen.?

Undang-Undang Perlindungan Konsumen menyatakan bahwa, perlindungan konsumen adalah segala upaya yang menjamin adanya kepastian hukum untuk memberi perlindungan kepada konsumen. Cakupan perlindungan konsumen itu dapat dibedakan dalam dua aspek, yaitu: ${ }^{8}$

a. Perlindungan terhadap kemungkinan barang yang diserahkan kepada knnsumen tidak sesuai dengan apa yang telah disepakati

b. Perlindungan terhadap diberlakukannya syarat-syarat yang tidak adil kepada konsumen.

Az. Nasution berpendapat bahwa hukum perlindungan konsumen adalah bagian dari hukum konsumen yang memuat asas-asas atau kaidah-kaidah yang bersifat mengatur dan mengandung sifat yang melindungi kepentingan konsumen, sedangkan hukum konsumen adalah hukum yang mengatur hubungan dan masalah antara berbagai pihak satu sama lain berkaitan dengan barang atau jasa konsumen di dalam pergaulan hidup. ${ }^{9}$

\footnotetext{
${ }^{5}$ Celina Tri Siwi Kristiyanti. 2019. Hukum Perlindungan Kansumen. Jakarta: Sinar Grafika. Hal: 78

${ }^{6}$ lbid. Hal: 82

${ }^{7}$ Erman Rajagukguk. 20ID. Pentingnya Hukum Perlindungan Kansumen dalam Era Perdagangan Bebas. Bandung: Mandar Maju. Hal: 44

${ }^{8}$ Adrianus Meliala. 2016. Praktik Bisnis Curang. Jakarta: Pustaka Sinar Harapan. Hal:89

${ }^{9}$ Az. Nasution. 2011. Hukum Perlindungan Kansumen Suatu Pengantar. Jakarta: Diadit Media. Hal: IZI
}

Transaksi Lual Beli Sampah Dalam Perspektif Hukum Perlindungan Kansumen (Studi pada Kaperasi Bank Sampah Sunggal Mandiri, Paya Bakung Kabupaten Deli Serdang) 
Bank Sampah Sunggal Mandiri merupakan salah satu bank sampah yang dimiliki oleh pemerintahan kata Medan. Dalam hal ini, konsumen berhak mendapatkan kejelasan mengenai spesifikasi tentang barang-barang yang akan mereka beli baik dari segi kualitas, kuantitas maupun harga yang sewajarnya untuk barang tersebut. Sehingga kandisi ini mengakibatkan kedudukan pelaku usaha dan knnsumen menjadi tidak seimbang dan konsumen berada dalam posisi yang lemah.

Banyak faktor yang membuat kansumen tidak sadar jika banyak hal yang dirugikan ketika bertransaksi dalam jual beli di antaranya:

1. Konsumen menjadi objek aktifitas bisnis yang dapat diraup keuntungan sebesar-besarnya.

2. Rendahnya kesadaran konsumen disebabkan oleh rendahnya pendidikan konsumen

Oleh karena itu, Undang-Undang №. 8 Tahun 1999 tentang Perlindungan kansumen dimaksud menjadi landasan hukum yang kuat bagi pemerintah dan lembaga perlindungan konsumen sebagai upaya pemberdayaan konsumen melalui pembinaan dan melindungi segala aktifitas muamalah yang merugikan pihak konsumen.

Menurut pendapat salah satu konsumen, menjelaskan bahwa kehadiran Bank Sampah Sunggal Mandiri memberikan keuntungan "Kita dapat menjual dengan harga yang kita tahu di pasaran, kalau kerugian bila kita tidak tahu harga barang yang akan kita jual maka kita akan rugi" I0 Masyarakat sebagai produsen sampah, sudah terlebih dahulu menyortir atau memilah sampah di rumahnya masing-masing. Setelah sampah dipilah oleh masyarakat, barulah sampah pilihan tersebut disetarkan ke bank sampah. Dalam proses pengumpulan ini, sampah ditimbang dihadapan nasabah, kemudian petugas menuliskan sejumlah nilai rupiah sampah menurut klasifikasinya di buku tabungan nasabah.

Sampah yang sudah terkumpul di Bank Sampah, kemudian diolah menjadi beberapa kerajinan tangan atau pun pupuk kompos. Dan sampah-sampah yang tidak bisa dijadikan kerajinan tangan akan dijual ke pengepul dan ke pihak yang sudah menjadi mitra Bank Sampah. Bila kita melihat transaksi yang dilakukan aleh bank sampah dan nasabah selintas saja, maka kita akan menilai bahwa transaksi yang dilakukan seperti transaksi biasa. Dalam jual beli, jika si penjual telah mendapatkan hak atas kepindahan kepemilikan barang dan si pembeli telah mendapatkan barang yang diinginkan maka hubungan antara penjual dan pembeli telah terputus. Ini semua tidak sama dengan hal kerjasama. Di dalam kerjasama, hubungan ini bersifat terus menerus selama bisnis yang dilakukan tetap ada dan salah satu pihak tidak memutuskan hubungannya atas lainnya.

\footnotetext{
${ }^{10}$ Wawancara dengan Jaya Winata selaku Konsumen pada hari Kamis, 27 Mei 2021 pukul 13.15 WIB 
Dalam pengumpulan, pengelolaan, dan pemanfaatan nilai ekonomis sampah, Bank Sampah bekerjasama dengan masyarakat. Masyarakat yang langsung memberikan kontribusinya dalam pengumpulan dan pemilahan sampah, sedangkan Bank Sampah bertugas untuk mengelola sampah agar sampah yang telah disetorkan dapat memberikan nilai ekonamis lebih. Uang yang dihasilkan dari penjualan sampah atau pun penjualan kerajinan tangan tersebut dibagi sesuai kesepakatan. Maksud dari kesepakatan ini adalah kesepakatan akan pembagian rupiah (nilai sampah) yang telah ditetapkan.

Dari kegiatan di atas, kita bisa melihat bahwa kedua belah pihak memberikan knntribusinya dalam mengelola sampah yang tidak bernilai apa-apa berubah menjadi barang yang mempunyai nilai ekonamis. Nasabah atau masyarakat memilah sampah rumah tangga yang ada di rumah mereka masing-masing sebelum disetorkan ke bank sampah. Sedangkan Bank Sampah mengelola sampah yang telah disetorkan tadi untuk dijadikan kerajinan tangan dan kompos. Sisa dari sampah yang dikumpulkan akan dijual ke pengepul.

Sebagaimana di atur pada pasal 4 ayat I Undang-Undang Perlindungan Konsumen No.8 tahun 1999, konsumen atau pembeli properti memiliki hak antara lain kenyamanan, keamanan, dan keselamatan dalam mengknnsumsi produk maupun jasa serta memilihnya sesuai dengan nilai tukar dan kondisi sesuai perjanjian. Sehingga jika dianalisis dengan hak-hak konsumen pasal 4 Undang-Undang Perlindungan Konsumen, ada beberapa ayat yang tidak diterapkan yaitu pada ayat di antaranya: Hak untuk memilih barang dan/atau jasa serta mendapatkan barang dan/atau jasa tersebut sesuai dengan nilai tukar dan kondisi serta jaminan yang dijanjikan (ayat 2). Hak atas infarmasi yang benar, jelas, dan jujur mengenai kondisi dan jaminan barang dan/atau jasa (ayat 3) dan Hak untuk mendapat pembinaan dan pendidikan konsumen (ayat G).

\section{KESIMPLLAN}

I. Praktek jual beli sampah di Bank Sampah Sunggal Mandiri dengan warga yaitu dalam pengumpulan, pengelolaan, dan pemanfaatan sampah, dimana masyarakat yang langsung memberikan kontribusinya dalam pengumpulan dan pemilahan sampah, sedangkan Bank Sampah bertugas untuk mengelola sampah agar sampah yang telah disetorkan dapat memberikan nilai ekonomis lebih. Uang yang dihasilkan dari penjualan sampah dibayarkan sesuai kesepakatan. Sampah yang sudah terkumpul di Bank Sampah, kemudian diolah menjadi beberapa kerajinan tangan atau pun pupuk kompos. Dan sampah-sampah yang tidak bisa dijadikan kerajinan tangan akan dijual ke pengepul dan ke pihak yang sudah menjadi mitra Bank Sampah. 
2. Jika dianalisis dengan hak-hak knnsumen pasal 4 UUIPK, ada beberapa ayat yang tidak diterapkan yaitu pada ayat di antaranya: Hak untuk memilih barang dan/atau jasa serta mendapatkan barang dan/atau jasa tersebut sesuai dengan nilai tukar dan kondisi serta jaminan yang dijanjikan (ayat 2). Hak atas informasi yang benar, jelas, dan jujur mengenai kondisi dan jaminan barang dan/atau jasa (ayat 3) dan Hak untuk mendapat pembinaan dan pendidikan konsumen (ayat B).

\section{DAFTAR PUSTAKA}

\section{Buku}

A. Qorim Syamsudin Meliala. 20I0., Pokok-Pakak Hukum Perjanjian Beserta Perkembangannya, Yogyakarta: Liberty

Abdul Halim Barkatulah. 2018., Hukum Perlindungan Kansumen (Kajian Tearetis dan Perkembangan Pemikiran). Bandung: Nusa Media

Abdul R. Saliman. 2015., Hukum Bisnis Untuk Perusahaan: Teari dan Cantah Kasus, Jakarta: Kencana

Adrianus Meliala. 2016., Praktik Bisnis Lurang, Jakarta: Pustaka Sinar Harapan

Ahmad Ali. 2012., Menguak Tabis Hukum (Suatu Kajian Filosafis dan Sasialogis), Jakarta: Gunung Agung

Az. Nasution. 201l.. Hukum Perlindungan Kansumen Suatu Pengantar, Jakarta: Diadit Media

Bambang Suwerda. 2016., Bank Sampah, Yogyakarta: Pustaka Rihama

Celina Tri Siwi Kristiyanti. 2019., Hukum Perlindungan Kansumen, Jakarta: Sinar Grafika

Djohari Santoso dan Achmad Ali. 2019., Hukum Perjanjian Indanesia, Yogyakarta: Perpustakaan Fakultas Hukum Universitas Islam Indonesia

Eka Utami. 2013., Buku Panduan Sistem Bank Sampah dan IL Kisah Sukses, Jakarta : Yayasan Unilever Indanesia.

Eni Setyawati. 2014., Sampah Aktualisasi Nilai-Nilai Islam, Ekonomi Sasial dan Budaya, Yagyakarta : IAIN Tulungagung Press.

Erman Rajagukguk. 20ID., Pentingnya Hukum Perlindungan Kansumen dalam Era Perdagangan Bebas, Bandung: Mandar Maju

Happy Susanto. 2018., Hak-Hak Kansumen Jika Dirugikan, Jakarta: Visimedia

Kasmir. 2018., Bank dan Lembaga Keuangan Lainnya, cetakan ke Sembilan belas, Jakarta: PT. Raja Grafindo Persada

Nindyo Pramono. 2016., Bunga Rampai Hukum Bisnis, Let. 8, Bandung: Citra Aditya Bakti,

Rizki Sukma Hapsari. 20ID., Perjanjian Baku dalam Praktik Perusahaan Perdagangan, Bandung: Citra Aditya Bakti

Roem Topatisamang, dkk. 2010., Menggeser Neraca kekuatan: Panduan Pelatihan Pendidikan Kansumen untuk Pemula, لakarta: YLKI

Subekti. 2015., Aneka Perjanjian, Bandung: Intermasa

\section{Peraturan Perundang-undangan}

Undang-Undang Nomor I0 Tahun 19988 tentang Perbankan

Undang-Undang Nomor 18 tahun 2008 tentang Pengelolaan Sampah

Jurnal

Sri Handayani. 20I2., Aspek Hukum Perlindungan Knnsumen dalam Pelayanan Air Bersih pada PDAM Tirtasari Binjai, Jurnal Non Eksakta (Volume 4 Nomor I).

Kornelius Benuf. (2020).. Urgensi Kebijakan Perlindungan Terhadap Konsumen Fintech Peer To Peer Lending Akibat Penyebaran Covid-IS, Jurnal Rechsvinding, Vol. 9 No, 2. 
ISSN (print) : 2722-7316

e-ISSN : :2723-1275

https://ejournal.uhn.ac.id/index.php/humaniora/

Yuyut Prayutiz, Riska Yulianti, Indra Yutik, (2020)., Perlindungan Hukum dalam Sengketa antara Kansumen Kendaraan Bermator dengan Lembaga Pembiayaan Dihubungkan dengan Uل No. 8 Tahun 1999 tentang Perlindungan Kansumen, PAJDUL (Pakuan Justice Jaurnal Of Law), Vol. DI, №. DI. 